Marzena Blachowska-Szmigiel

Uniwersytet Adama Mickiewicza Instytut Filologii Romańskiej

\title{
ZADANIA ZORIENTOWANE NA EKSPRESJĘ TEATRALNĄ JAKO NARZĘDZIE WSPIERAJĄCE ROZWÓJ KREATYWNOŚCI JĘZYKOWEJ STUDENTA FILOLOGII ROMAŃSKIEJ
}

\begin{abstract}
Tasks using dramatic expression as a tool to support
development of the linguistic creativity of students of French

The goal of this paper is to outline the possibilities of the use of drama techniques as a tool to support development of the linguistic creativity of students of French. The paper consists of three parts. In parts 1 and 2 the author presents the theoretical foundations of the teaching techniques proposed, and these are then presented in part 3.
\end{abstract}

Kreatywność językowa ucznia języka obcego jest szczególnym rodzajem twórczości szkolnej, ze względu na znaczenie, jakiego w tym przypadku nabiera interakcja między myśleniem/myślą a językiem docelowym. Poziom biegłości językowej wyznacza gradację celów zorientowanych na rozwijanie dyspozycji twórczych ucznia, a ich rozwój ma wpływać na jakość jego zachowań językowych w języku docelowym (Blachowska-Szmigiel 2010). Mówiąc językiem opisu kompetencji ESOKJ (Conseil de l'Europe 2001), oznacza to konieczność ścisłej koordynacji gradacji celów zorientowanych na rozwijanie językowych kompetencji komunikacyjnych (lingwistycznych, socjolingwistycznych i pragmatycznych) i gradacji celów zorientowanych na rozwijanie kompetencji ogólnych w zakresie uwarunkowań osobowościowych swoistych dla zachowań twórczych podmiotu. Jedno zatem z podstawowych pytań, które zadaje sobie nauczyciel prowadzący warsztaty kreatywności językowej dotyczy tego, czy i w jakim stopniu proponowane przez niego zadania, techniki pracy, środki i narzędzia dydaktyczne spełniają powyższy warunek. 
W niniejszym artykule zadaję sobie to właśnie pytanie w odniesieniu do zadań zorientowanych na ekspresję teatralną jako narzędzia wspierającego rozwijanie kreatywności językowej studenta filologii romańskiej. W części pierwszej („Wiek XXI jako stulecie homo creativus”) i części drugiej („Nauczanie/uczenie się języka obcego jako psychospołeczna kategoria aktywności twórczej") artykułu wprowadzam czytelnika w kontekst badań i refleksji nad rozwijaniem kreatywności językowej ucznia języka obcego. Ich zasadniczym celem jest określenie fundamentów teoretycznych dla przyjętej praktyki dydaktycznej, którą omawiam w części trzeciej („Rozwijanie kreatywności językowej studentów filologii romańskiej - poziom biegłości językowej B1").

\section{Wiek XXI jako stulecie homo creativus}

\subsection{Ewolucja psychologicznych koncepcji człowieka twórczego}

Psychologia końca XIX wieku interesuje się twórczością artystyczną, synonimem twórcy w tamtym czasie jest pisarz i poeta, których uważa się, jako jedynych przedstawicieli świata sztuki, za obdarowanych mocą porównywalną do boskiej mocy "tworzenia z niczego". Dla psychologii twórczości początków XXI wieku twórcą jest po prostu człowiek, który w różnych dziedzinach swojej aktywności zachowuje się w sposób nowy, oryginalny i wartościowy w perspektywie indywidualnej i/lub społecznej. Nowość, oryginalność i wartość jego zachowań znajduje odzwierciedlenie w cechach jego wytworów lub w postawie życiowej. Etapy ewolucji paradygmatu personologicznego w psychologicznych badaniach twórczości wyznaczają koncepcje człowieka twórczego wypracowane w psychoanalizie, behawioryzmie, psychologii poznawczej i psychologii humanistycznej.

W paradygmacie psychoanalitycznym „twórca-artysta” (pisarz i poeta) dzięki mechanizmom sublimacji (według Z. Freuda) czy regresji adaptacyjnej w służbie ego (zdaniem E. Krisa) (Szmidt 2001) wykorzystuje energię popędów i impulsów do pracy, by w konsekwencji przekształcić swoje pragnienia i fantazje w wytwór społecznie akceptowalny. Nie jest to jednak przywilej przeciętnego człowieka, choć zdaniem przedstawicieli nurtu psychoanalitycznego wszyscy mamy zadatki by stać się twórcami, ponieważ twórczość jest kontynuacją aktywności zabawowej (Blachowska-Szmigiel 2010). Według behawiorystów człowiek jest zewnątrzsterowny, zatem zachowania nowe, oryginalne i produktywne można wzmacniać przez odpowiednią stymulację (Nęcka 2001). Psychologowie poznawczy natomiast postrzegają twórczość jako immanentną cechę umysłu ludzkiego, o ciągłym i złożonym charakterze. 
Każdy człowiek jest więc potencjalnie twórczy, co więcej jako jednostka wewnątrzsterowna sam kieruje własnym rozwojem wyznaczając sobie kolejne cele i zadania, może zatem w sposób świadomy rozwijać własne dyspozycje twórcze. Badania psychologów poznawczych wykazują, że nie ma jednego typu umysłu twórczego, ani ściśle określonego zbioru dyspozycji twórczych (Nęcka 2001). Dla psychologów humanistycznych - krytykowanych za spekulatywny charakter swoich rozważań (Popek 2003), człowiek twórczy to jednostka, która kieruje się w życiu potrzebą samorealizacji. Twórczość jest w ujęciu przedstawicieli tego nurtu w większym stopniu kwestią stylu bycia i filozofii życiowej, niż kwestią dyspozycji.

\section{2. „Twórczość przez małe t”}

Zarysowane powyżej koncepcje człowieka twórczego ilustrują wyraźne przesunięcie akcentów w psychologicznych badaniach twórczości z podejścia elitarnego - dominującego jeszcze w pierwszej połowie XX wieku, na podejście egalitarne - stopniowo zyskujące na znaczeniu począwszy od lat 60., wraz z rozwojem paradygmatów poznawczych i upowszechnianiem się idei psychologów humanistycznych. Podejście elitarne określane w literaturze przedmiotu jako "twórczość wysoka”, „twórczość przez duże T” (Nęcka 2001: 20) czy „twórczość historyczna" (Kozielecki 2000: 186) wiąże się z koniecznością stworzenia dzieła, które w ocenie społecznej (ekspertów) uznane zostanie za nowe, oryginalne i wartościowe. Podejście egalitarne nazywane także „twórczością niską", „twórczością przez małe t” (Nęcka 2001: 21-22) czy „twórczością psychologiczną" (Kozielecki 2000: 186) nie stawia takich wymagań przed jednostką twórczą, co więcej akceptuje także ideę „twórczości bez dzieł” reprezentatywną dla psychologów humanistycznych (Nęcka 2001: 23-24).

W konsekwencji, począwszy od drugiej połowy XX wieku znaczenia nabiera proces tworzenia i rozwijanie dyspozycji twórczych przez treningi twórczości. Wiek XXI należy bezsprzecznie do homo creativus, bez względu na wiek, płeć czy dziedzinę aktywności zawodowej. Programy unijne wspierają ideę rozwoju przez całe życie, rośnie popularność uniwersytetów trzeciego wieku, media promują talenty, a w Internecie łatwo znaleźć ogłoszenia o warsztatach i treningach kreatywności organizowanych przez różne instytucje. W potocznym obiegu pojęcie twórczości, odmieniane jest przez wszelkie możliwe przypadki, w rezultacie traci na ostrości i ulega rozmyciu. Każdy intuicyjnie wie, co znaczy „być twórczym”, niewielu jednak potrafi twórczość zdefiniować bez uciekania się do tautologizmów w rodzaju „bycie twórczym to bycie kreatywnym". W badaniach psychologicznych, poszukiwanie uniwersalnej wykładni twórczości reprezentatywne dla pierwszej połowy XX wieku 
(Stasiakiewicz 1999) ustępuje miejsca z jednej strony badaniom poznawczych i emocjonalno-motywacyjnych mechanizmów aktywności twórczej (podejście poznawcze) oraz typów umysłów twórczych czy twórczych stylów poznawczych (podejście typologiczne), z drugiej badaniom psychospołecznych kategorii aktywności twórczej (podejście interakcyjne).

\subsection{Psychospołeczne kategorie aktywności twórczej}

Badania psychospołecznych kategorii aktywności twórczej wymagają uwzględnienia powiązań między następującymi paradygmatami twórczości:

- paradygmatem osoby, który skupia się na badaniu twórczych cech i dyspozycji osobowych, oraz odsyła do kryterium wieku, rodzaju aktywności (szkolna/zawodowa) czy wykonywanego zawodu;

- paradygmatem procesu, który odnosi się do myślenia twórczego oraz do właściwości i przebiegu procesu twórczego, a także skłania do refleksji na temat rodzaju zadania wykonywanego przez podmiot (indywidualne/grupowe, otwarte/zamknięte, werbalne/niewerbalne);

- paradygmatem ekologicznym, w ramach którego bada się cechy środowiska twórczego, i który upoważnia do wyróżnienia środowiska bliższego (rodzina, grupy formalne i nieformalne) i dalszego (kontekst społeczno-kulturowy), środowiska nauki i środowiska pracy;

- paradygmatem produktu (odkrycie, wynalazek, dzieło, produkt działalności publicznej), który odnosi się do właściwości rezultatu aktywności twórczej i ukierunkowuje refleksję badawczą również na obszary aktywności (tj. naukę, technikę i sztukę), środki ekspresji (językowe, niejęzykowe), cele (estetyczne, poznawcze, etyczne) oraz perspektywę oceny (indywidualną, społeczną).

Wyżej wymienione paradygmaty wykształciły się w drugiej połowie ubiegłego stulecia i stanowią punkt odniesienia dla wyodrębnienia bardziej szczegółowych kryteriów kategoryzacji aktywności twórczej.

Badania psychospołecznych kategorii aktywności twórczej pozwalają $z$ jednej strony uchwycić, a w dalszej konsekwencji uporządkować różnorodność jej przejawów, z drugiej strony potwierdzają uniwersalny charakter jej uwarunkowań poznawczych i emocjonalno-motywacyjnych. Niezależnie od psychospołecznej kategorii aktywności twórczej, jednym z jej kluczowych uwarunkowań wewnątrzpsychicznych pozostaje bowiem:

- w sferze poznawczej struktur osobowości myślenie synwergentne (tj. myślenie, które charakteryzuje dynamiczna równowaga między przetwarzaniem konwergencyjnym a przetwarzaniem dywergencyjnym); 
- w sferze emocjonalno-motywacyjnej struktur osobowości „konformizmnonkonformizm" rozumiany jako złożony, dwubiegunowy wymiar o ciągłym charakterze (Popek 2004).

„Konformizm-nonkonformizm" reguluje i aktualizuje twórcze, poznawcze funkcjonowanie podmiotu facylitując je bądź hamując (w zależności od struktury i natężenia poszczególnych cech wchodzących w zakres tego wymiaru).

Inaczej mówiąc u podstaw zachowań twórczych nauczyciela, ucznia, menedżera, pisarza, poety czy malarza leżą:

- w sferze poznawczej zdolność generowania wielu zróżnicowanych pomysłów i wyboru tego spośród nich, który zostanie zrealizowany;

- w sferze emocjonalno-motywacyjnej między innymi takie cechy jak wysokie poczucie wartości Ja, samokrytycyzm, otwartość, elastyczność adaptacyjna czy konsekwencja składające się na postawę nonkonformistyczną (Blachowska-Szmigiel 2010).

Swoistość zaś kreatywności w różnych psychospołecznych kategoriach aktywności twórczej wyznaczają: dziedzina aktywności, zadanie i środki ekspresji (językowe/ niejęzykowe). Z perspektywy poznawczej biegłość użycia językowych/niejęzykowych środków ekspresji uwarunkowana jest biegłością z jaką umysł/mózg przetwarza informacje językowe/niejęzykowe (tj. biegłością językowego i niejęzykowego systemu przetwarzania informacji), a biegłość tę warunkują struktura i poziom zdolności intelektualnych. Dodać należy, że językowy i niejęzykowy system przetwarzania informacji aktywizują się i współpracują w swoisty sposób w zależności od środków ekspresji wymaganych podczas realizacji określonego zadania i dziedziny aktywności. Inaczej mówiąc, pisarz wyraża słowem, to co malarz oddaje kreską, kształtem czy kolorem. Od pierwszego zatem nie będziemy wymagać zdolności plastycznych, a drugiemu wybaczymy szorstkość stylu, czy niską płynność słowną.

\section{Nauczanie/uczenie się języka obcego jako psychospołeczna kategoria aktywności twórczej}

\subsection{Swoistość twórczości szkolnej}

W pedagogice twórczość szkolna nie jest tematem nowym, by przywołać idee M. Montessori, J. Deweya, C. Freineta czy H. Rowida (Blachowska-Szmigiel 2010). Nową jakość wnosi natomiast jej ujęcie jako jednej z wielu psychospołecznych kategorii aktywności twórczej. Swoistość twórczości szkolnej wyznaczają przede wszystkim takie zmienne jak: szkoła jako miejsce nauki i miejsce 
pracy, przedmiot, stosowane metody i środki nauczania, postawa nauczyciela i postawa ucznia. Przejdźmy do ich bardziej szczegółowego omówienia.

Rola szkoły jako zmiennej wyznaczającej swoistość zachowań twórczych ucznia/nauczyciela pozostaje dyskusyjna. Z jednej strony bowiem szkoła to miejsce, w którym promuje się talenty (na poszczególnych szczeblach edukacji), z drugiej zaś miejsce, w którym wygasza się zachowania twórcze uczniów/nauczycieli, (np. przez ujednolicanie myślenia i zachowania, zaostrzanie dyscypliny, przekazywanie „wiedzy jałowej” (Nęcka 2001: 149-150) zamiast rozwijania dociekliwości oraz umiejętności dostrzegania problemów i wrażliwości na sytuacje problemowe itd.

Przedmiot jako zmienna wyznaczająca swoistość twórczości szkolnej określa formę rezultatu szkolnej twórczości ucznia i rodzaj aktywizowanych/rozwijanych zdolności. Dla przykładu wynikiem aktywności twórczej ucznia podczas zajęć z fizyki jest odkrycie, zajęć praktyczno-technicznych wynalazek, a zajęć z języka ojczystego/obcego twórczość literacka (Blachowska-Szmigiel 2010). Oczywiście w każdym z wymienionych przypadków rezultat jest twórczy w wymiarze indywidualnym (chyba, że naszym uczniem jest osobowość na miarę R.J. Fichera czy A. Turinga). Stopień jego nowości i oryginalności (a w konsekwencji także wartości) oceniany jest w stosunku do efektów kształcenia planowanych na danym etapie edukacji oraz w stosunku do zakładanych celów poznawczych zorientowanych na rozwijanie dyspozycji twórczych ucznia (np. rozwijanie wyobraźni, myślenia dywergencyjnego).

Swoistość twórczości szkolnej określają także metody i środki nauczania stymulując bądź wygaszając zachowania twórcze. Do metod stymulujących zachowania twórcze zaliczają się te, które aktywizują myślenie heurystyczne i co więcej skłaniają ucznia do stosowania zróżnicowanych heurystyk. Przykładem takich metod w odniesieniu do nauczania języka obcego mogą być dyskusja poprowadzona według techniki sześciu kapeluszy myślowych E. de Bono (de Bono 1986) i projekt. Środki nauczania same w sobie nie przedstawiają wartości dla rozwijania zachowań twórczych, liczy się umiejętność ich różnicowania oraz cel, w jakim są wykorzystywane, np. tablica i kreda, wykorzystywane podczas burzy mózgów do zapisywania pomysłów versus tablica i kreda wykorzystywane do zapisywania reguł, które uczeń ma zanotować i zapamiętać. W pierwszym przypadku stymulujemy myślenie dywergencyjne, $\mathrm{w}$ drugim rozwijamy myślenie konwergencyjne i zachowania konformistyczne.

Podobnie jak metody i środki nauczania postawa nauczyciela jest zmienną stymulującą bądź wygaszającą twórcze zachowania uczniów. We współczesnej literaturze glottodydaktycznej nauczyciela języków obcych określa się jako eksperta, który organizuje, doradza, pośredniczy, kontroluje, ocenia, wychowuje, wprowadza innowacje, a wśród kompetencji, którymi 
powinien się cechować, wymienia się kompetencje innowacyjno-kreacyjne (Zawadzka 2004). Od nauczyciela oczekuje się między innymi zdolności samokształcenia, zdolności adaptacyjnych i mobilności (Blachowska-Szmigiel 2010). Nauczyciel o takich kompetencjach, pozostaje otwarty na zachowania twórcze ucznia oraz na metody i techniki stymulujące ich rozwój.

Ostatnią z wymienionych wcześniej zmiennych wyznaczających swoistość twórczości szkolnej jest postawa ucznia. Ukierunkowuje ona czynności nauczyciela, wpływa na wybór metod i technik pracy oraz organizację procesu nauczania. Dla przykładu uczeń przejawiający zachowania konformistyczne i myślenie konwergencyjne preferuje zadania zamknięte poprzedzone dokładną instrukcją, poza tym lubi wiedzieć, czy dobrze wykonuje zadanie, a więc najprawdopodobniej będzie zadawał nauczycielowi dodatkowe pytania przed podjęciem aktywności i $w$ jej trakcie. Wzmocnienie u takiego ucznia zachowań nonkonformistycznych wymaga od nauczyciela specyficznych działań pedagogicznych. Jak pisze R. E. Bernacka: „Istotne w postępowaniu (...) z dziećmi konformistycznymi wydaje się dążenie do wyrabiania u nich pewności siebie. $Z$ jednej strony chodzi o oddziaływanie na system poznawczy, a z drugiej stwarzanie konformiście sposobności do doświadczania świata i swoich z nim relacji w inny sposób" (Bernacka 2004: 122).

Podsumowując, twórczość szkolna ma indywidualny wymiar i procesualny charakter. Polega ona przede wszystkim na stymulowaniu dyspozycji twórczych ucznia (poznawczych, emocjonalno-motywacyjnych), przy czym kolejne etapy ich rozwoju oraz kryteria oceny wytworów twórczości szkolnej wyznaczane są przez ramy programowe. Produkty twórczości szkolnej są ponadto dla nauczyciela źródłem informacji na temat stopnia realizacji celów poznawczych zorientowanych na rozwijanie dyspozycji twórczych ucznia.

\subsection{Twórczość językowa na lekcji języka obcego jako podkategoria szkolnej twórczości językowej}

Tak na lekcji języka obcego jak na lekcji języka ojczystego twórczość językowa przejawiać się może z jednej strony w nowości, oryginalności i wartości myśli, której uczeń po prostu nadaje formę werbalną korzystając ze środków systemu języka ojczystego/obcego; z drugiej strony w nowości, oryginalności i wartości formy werbalnej, którą uczeń nadaje treściom utartym, a ponadto w tworzeniu form werbalnych nowych, oryginalnych i wartościowych.

Swoistość twórczości językowej ucznia języka obcego wyznacza poziom jego biegłości językowej w języku docelowym. W uproszczeniu, im niższy poziom kompetencji komunikacyjnej w języku docelowym, tym większa bariera dla kreatywności językowej ucznia języka obcego. W konsekwencji 
poziom biegłości językowej stanowi dla nauczyciela punkt odniesienia podczas określania gradacji celów zorientowanych na rozwijanie dyspozycji twórczych ucznia języka obcego przejawiających się w jego zachowaniach językowych. Biorąc pod uwagę poziomy biegłości językowej (Conseil de l'Europe 2001) kreatywność językowa ucznia języka obcego, a więc jego twórcza kompetencja komunikacyjną, o której pisałam obszerniej przy innej okazji (Blachowska-Szmigiel 2011, Blachowska-Szmigiel, Moreau 2011) wyraża się między innymi w umiejętnościach:

- podkreślania unikalnych i wielozmysłowych cech obiektów (tzn. ludzi, zwierzęta, rzeczy i aktywności) i relacji między nimi (od poziomu A1-A2),

- opisywania obiektów i zdarzeń w sposób metaforyczny, z perspektywy osobistej i nieantropocentrycznej (od poziomu B1-B2),

- podkreślania wyjątkowego charakteru zdarzeń (od poziomu B1-B2),

- ujmowania zdarzeń i zjawisk z różnych punktów widzenia, z różnych perspektyw, dynamicznie (od poziomu C1-C2),

- konstruowania zniuansowanej, wiarygodnej i oryginalnej argumentacji wskazującej na świeże spojrzenie na podejmowany problem (od poziomu C1-C2),

- ujmowanie problemu z różnych perspektyw (od poziomu C1-C2).

Gradacja twórczych umiejętności komunikacyjnych, co należy podkreślić, jest ściśle związana z gradacją celów komunikacyjnych każdego poziomu biegłości językowej, a produkt kreatywności językowej ucznia języka obcego (tekst pisemny/ustny), podlega ocenie z jednej strony pod względem oczekiwanych efektów kształcenia w zakresie twórczej kompetencji komunikacyjnej, z drugiej strony pod względem poprawności językowej i formalnej. Dla przykładu jeśli celem poznawczym sekwencji zajęć językowych jest rozwijanie percepcji wielozmysłowej, a celem komunikacyjnym (w jego wymiarach lingwistycznym, socjolingwistycznym i pragmatycznych) rozwijanie umiejętności redagowania tekstów opisowych, to w siatce oceny twórczego opisu należałoby uwzględnić, poza poprawnością językową (na poziomach ortografii, morfo-składni i semantyki), spójnością formalną i pojęciową oraz poprawnością strony redakcyjnej (tj. podział na akapity, marginesy, czytelność pisma), kryterium płynności i giętkości słownej w zakresie werbalizowania wielozmysłowych wrażeń percepcyjnych. Płynność słowna w wyżej wymienionym zakresie odnosi się do łatwości posługiwania się różnorodną leksyką (synonimami, parasynonimami) wrażeń zmysłowych (wzrokowych, węchowych, smakowych, dotykowych, smakowych), giętkość zaś przejawia się w oryginalności opisu wrażeń zmysłowych (np. w krzyżowaniu wrażeń zmysłowych, któremu odpowiada zjawisko synestezji; czy stosowaniu w tym celu metafor i odległych skojarzeń). 


\section{Rozwijanie kreatywności językowej studentów filologii romańskiej - poziom biegłości językowej B1}

\subsection{Warsztaty kreatywności językowej - charakterystyka}

Szczegółową charakterystykę warsztatów kreatywności językowej, które realizujemy w ramach bloku zajęć z praktycznej nauki języka francuskiego (PNJF) zawarłam w artykule "Le va-et-vient entre le polonais et le français en atelier de la créativite langagière" (Blachowska-Szmigiel, Moreau 2011), w tym miejscu ograniczę się do przypomnienia zasad organizacyjnych i celów warsztatów oraz podania przykładowych zadań. Warsztaty trwają dwa semestry (60 godz.) i zorganizowane są tematycznie, a ich zasadniczym celem jest rozwijanie płynności i giętkości myślenia przejawiającej się w płynności słownej, ideacyjnej i skojarzeniowej oraz giętkości spontanicznej i adaptacyjnej. Inaczej mówiąc, stosując techniki aktywizujące myślenie synwergentne (np. diagram ryby, mapa myśli, 6 myślowych kapeluszy, implikacje czy gra Tabu) rozwijamy, w zakresach tematycznych poruszanych na zajęciach, łatwość doboru słów, spontanicznego wypowiadania się (ustnego/pisemnego), wymyślania w krótkim czasie wielu tematów do dyskusji oraz wytwarzania nowych jakościowo pomysłów. Przykładowe zadania realizowane przez studentów (grupowo i indywidualnie) to: prezentacje multimedialne, gry, wystąpienia przygotowywane w oparciu o diagramy ryby i mapy myśli, scenki rodzajowe.

\subsection{Aktywność teatralna na warsztatach kreatywności językowej}

Obserwując zachowania niewerbalne/parawerbalne i werbalne studentów podczas warsztatów kreatywności językowej zauważyliśmy, że często ich komunikatom brakuje spójności na poziomie werbalnym i niewerbalnym/parawerbalnym. Ponadto pewną trudność sprawia studentom formułowanie komentarzy do zachowań niewerbalnych/parawerbalnych, np. bohaterów filmowych. W konsekwencji, od roku akademickiego 2011/2012 uzupełniliśmy wymienione wyżej cele warsztatów kreatywności językowej o cele zorientowane na rozwijanie umiejętności:

- odczytywania/interpretowania emocji na podstawie zachowań niewerbalnych (wyrazów twarzy, gestów, postawy ciała) i parawerbalnych (intonacji, tonu głosu);

- przedstawiania emocji przez zachowania niewerbalne (wyraz twarzy, gesty, postawę ciała) i parawerbalne; 
- formułowania komunikatów spójnych na poziomie niewerbalnym/ parawerbalnym i werbalnym.

Choć wymienione wyżej umiejętności niewerbalne stanowią integralny komponent komunikacji interpersonalnej i wchodzą w zakres kompetencji społecznej, to w zinstytucjonalizowanym kontekście nauczania języka obcego są zazwyczaj pomijane albo sprowadzane do zagadnienia różnic kulturowych. Jedną z przyczyn tego stanu rzeczy jest najprawdopodobniej brak czasu, inną przekonanie, że umiejętności te - związane z większą aktywnością prawej półkuli mózgowej - jednostka rozwija w sposób intuicyjny wchodząc w interakcje międzyludzkie. Czyniąc z umiejętności niewerbalnych cel nauczania stymulujemy aktywność obu półkul mózgowych i przepływ informacji między nimi, co jest szczególnie istotne dla rozwoju myślenia twórczego ze względu na jego synwergentny charakter.

Narzędziem, które wręcz wymusza formułowanie celów zorientowanych na rozwijanie umiejętności niewerbalnych jest aktywność teatralna, pozwalająca w sposób naturalny połączyć komunikację werbalną i niewerbalną/parawerbalną na warsztatach kreatywności językowej. W omawianym kontekście, z uwagi na ograniczenia formalne, proponowaliśmy studentom zadania i sekwencje zadań zorientowane na ekspresję teatralną, które wieńczyły inscenizacje przygotowywane przez studentów. Wprowadzając zadania zorientowane na ekspresję teatralną posłużyliśmy się między innymi takimi środkami jak: filmy fabularne, filmy reklamowe, kreskówki czy sztuki teatralne. Włączyliśmy ją w sekwencje tematyczne warsztatów, przede wszystkim w taki sposób by:

- niewerbalne kompetencje receptywne (polegające na odczytywaniu/interpretacji odczuć emocji) rozwijać w interakcji z niewerbalnymi kompetencjami produktywnymi (których istotą jest umiejętność przedstawiania emocji, a w dalszej konsekwencji formułowania komunikatów spójnych na poziomie niewerbalnym/parawerbalnym i werbalnym);

- cele zorientowane na rozwój komunikacji językowej skoordynować z celami poznawczymi, emocjonalno-motywacyjnymi i interpersonalnymi.

Przejdźmy do przedstawienia fragmentu sekwencji zadań zrealizowanych na podstawie filmu "Le goût des autres" („Gusta i guściki”). Zadania wpisywały się w kontekst szerszej sekwencji tematycznej poświęconej relacjom interpersonalnym, rolom i stereotypom społecznym, tematom tabu, a film był jednym ze środków, które zastosowaliśmy. Przed obejrzeniem filmu pracowaliśmy na pojedynczych stopklatkach (bez napisów) przedstawiających głównych bohaterów, a po obejrzeniu na dłuższych fragmentach (jedna scena lub sekwencja scen). Poniżej charakteryzuję wybrane zadania zrealizowane przed obejrzeniem filmu: formułowanie hipotez i odgrywanie stanów emocjonalnych. 


\subsubsection{Formułowanie hipotez}

Zadanie polegało na formułowaniu hipotez odnoszących się do charakterystyki postaci (cech osobowych, zawodu, stylu bycia, przyzwyczajeń, mieszkania, itp.) i uzasadnianiu ich w oparciu o wygląd zewnętrzny postaci, na zasadzie skojarzeń oraz odwołania do stereotypów społecznych. Miało ono skłonić studentów do refleksji nad ograniczeniami (niebezpieczeństwami!) stereotypowego myślenia i wskazać możliwości „wykraczania” poza stereotypy dzięki myśleniu dywergencyjnemu, a jednocześnie uwrażliwić na znaczenie wyglądu zewnętrznego w postrzeganiu społecznym. Do realizacji tego zadania wykorzystałam technikę burzy mózgów, która rozwija myślenie dywergencyjne i konwergencyjne oraz umiejętność swobodnego „przełączania się" w trakcie procesu tworzenia z jednego typu myślenia na drugi. Podczas zajęć studenci indywidualnie formułowali hipotezy, które zapisywali na tablicy. W tej fazie, zgodnie z zasadami burzy mózgów, wszystkie pomysły były akceptowane. Następnie, po około 20 minutach, przeszliśmy do fazy oceniania hipotez, w której należało uzasadnić je w sposób przekonujący. W rezultacie, pozostawiliśmy hipotezy, które otrzymały najbardziej wiarygodne uzasadnienie i one właśnie stanowiły punkt wyjścia do realizacji kolejnego zadania polegającego na odgrywaniu stanów emocjonalnych.

\subsubsection{Odgrywanie stanów emocjonalnych}

Kolejne zadanie stanowiło przyczynek do dyskusji nad uniwersalnością i kulturowym nacechowaniem gestów oraz spójnością przekazu na poziomie werbalnym/niewerbalnym i parawerbalnym. Jego realizacja odbywała się w dwóch etapach. Etap pierwszy, realizowany indywidualnie $w$ domu, polegał na dopisaniu do stopklatki przedstawiającej bohatera filmu monologu wewnętrznego wraz z komentarzem na temat jego stanów emocjonalnych i odczuć oraz gestów i intonacji jakie mogłyby tym stanom i odczuciom towarzyszyć (np. smutny ton głosu, skulona postawa, skrzyżowanie rąk na piersi, poprawianie włosów itp.). Tekst monologu miał mówić o faktach, zdarzeniach, w których bohater brał udział, o ludziach których spotkał itp., emocje zaś i odczucia, które tym faktom, zdarzeniom czy spotkaniom towarzyszyły miały zostać wyrażone na poziomie parawerbalnym i niewerbalnym (tj. przez ton głosu, mimikę, gest, itp.) podczas ustnej prezentacji monologu bohatera. Długość monologu nie miała przekraczać jednej strony formatu A4. Drugi etap zadania odbywał się podczas warsztatów: poszczególni uczestnicy odgrywali monolog wewnętrzny swojego bohatera, a pozostałe osoby interpretowały/odczytywały odczucia/emocje i zapisywały swoje interpretacje na 
kartce w języku francuskim (np. „bohater jest zdenerwowany”, „mówi podniesionym głosem”, itp.). Po każdej prezentacji następowała krótka dyskusja i ocena stopnia czytelności odczuć/emocji oraz zgodności intencji z interpretacją. Podczas dyskusji uczestnicy mogli przechodzić na język ojczysty/polski, co zresztą wielu z nich robiło.

\section{Wnioski}

Kreatywność językowa ucznia języka obcego jako jeden z przejawów aktywności twórczej wpisuje się w szerszy kontekst badań i refleksji nad zjawiskiem twórczości, a rozwijanie kreatywności językowej na lekcji języka obcego nie wydaje się być przejściową modą, lecz jedną z konsekwencji ewolucji podejść i modeli nauczania/uczenia się w kierunku nauczania aktywizującego. W rezultacie organizacja warsztatów kreatywności językowej nie tyle wymaga od nauczyciela opanowania repertuaru narzędzi, technik czy środków dydaktycznych, co przyjęcia postawy refleksyjnego praktyka wyrażającej się między innymi w umiejętności ich holistycznego oglądu oraz oceny możliwości ich zastosowania do realizacji przyjętych celów i zakładanych efektów kształcenia.

W omawianym kontekście nauczania języka francuskiego na filologii romańskiej zadania zorientowane na ekspresję teatralną zostały zastosowane jako narzędzie wspierające rozwój kreatywności językowej, a w szczególności myślenia synwergentnego. Spotkały się one z pozytywną oceną studentów podczas końcowej ewaluacji zajęć. Ankietę wypełniło 30 osób i zdecydowana większość oceniła zajęcia jako „ciekawe” [80\%] i rozwijające umiejętności wymienione w sekcji 3.2. [75\%]. Ten wynik skłania do badań w celu potwierdzenia (weryfikacji!) wartość aktywności teatralnej jako narzędzia wspierającego rozwój myślenia synwergentnego.

\section{BIBLIOGRAFIA}

Bernacka, R.E. 2004. Konformizm i nonkonformizm a twórczość. Lublin: UMCS.

Blachowska-Szmigiel, M. 2010. Twórcze schematy poznawcze a kreatywność językowa. Na przykładzie języka francuskiego jako obcego. Poznań: Wydawnictwo Naukowe UAM.

Blachowska-Szmigiel, M., i Moreau A.-C. 2011. « Le va-et-vient entre le polonais et le français en atelier de la créativité langagière ». Studia Romanica XXXVIII/2. Poznań: Wydawnictwo Naukowe UAM: 73-85.

Blachowska-Szmigiel, M. 2011. « Nowość, oryginalność i wartość produkcji językowych ucznia języków obcych ». (w) Nauczanie języka obcego a specyficzne potrzeby uczqcych się. O kompetencjach, motywowaniu i strategiach (red. 
S. Piotrowski i J. Knieja). Prace Naukowe Wydziału Historyczno-Filologicznego 167. Lublin: Towarzystwo Naukowe KUL: 371-387.

Conseil de l'Europe 2001. Un cadre européen commun de référence pour les langue : apprendre, enseigner, évaluer. Paris: Conseil de l'Europe / Les Éditions Didier. de Bono, E. 1986. Six thinking hats. Harmondsworth, Middlesex: Penguin books.

Kozielecki, J. 2000. Koncepcje psychologiczne człowieka. Warszawa: Wydawnictwo Akademickie Żak.

Nęcka, E. 2001. Psychologia twórczości. Gdańsk: Gdańskie Wydawnictwo Psychologiczne Popek, S. 2003. Człowiek jako jednostka twórcza. Lublin: UMCS.

Stasiakiewicz, M. 1999. Twórczość i interakcja. Poznań: Wydawnictwo Naukowe UAM.

Szmidt, K.J. 2001. Szkice do pedagogiki twórczości. Kraków: Impuls.

Zawadzka, E. 2004. Nauczyciele języków obcych w dobie przemian. Kraków: Oficyna Wydawnicza „Impuls”. 